\title{
Provision of low cost media options for in vitro culture of Celosia sp.
}

\author{
Norhayati Daud ${ }^{1 \star}$, Rosna Mat Taha ${ }^{2}$, Nor Nafizah Mohd Noor ${ }^{1}$ and Hasimah Alimon ${ }^{1}$ \\ ${ }^{1}$ Department of Biology, Faculty of Science and Mathematics, Sultan Idris Education University, 35900 Tanjong Malim, \\ Perak, Malaysia. \\ ${ }^{2}$ Institute of Biological Sciences, Faculty of Science, University of Malaya, 50603 Kuala Lumpur, Malaysia.
}

Accepted 9 November, 2011

\begin{abstract}
The composition of culture medium used for shoot regeneration has a great influence on cost of materials making of media. This study was conducted to investigate the effect of using four kinds of commercial starch or flour as alternative gelling agents and coconut water as an organic additive in the culture medium on the number of shoots produced for eight weeks in culture. Explants from stem segments of Celosia sp were cultured on medium containing either half strength of Murashige and Skoog (MS) or without MS combined with $100 \mathrm{~g} / \mathrm{l}$ of each gelling agents and $70 \mathrm{ml} / \mathrm{l}$ coconut water. The findings showed that the use of young coconut water and alternative gelling agents have response to in vitro shoots regeneration of stem segments of Celosia sp. Higher revenue (12.33 \pm 7.27$)$ of shoots derived from stem segments results from the cultured media containing $100 \mathrm{~g} / \mathrm{l}$ of potato starch, $70 \mathrm{ml} / \mathrm{l}$ coconut water, household sugar and half strength concentration of MS ( $1 / 2 \mathrm{MS})$. Statistical analysis found no significant difference $(P>0.05)$ between culture media with different concentrations of MS with the number of shoots produced. The substitution of alternative gelling agents, use of coconut water and quantities of MS powder can reduce costs to medium preparation.
\end{abstract}

Key words: Alternative gelling agent, young coconut water, shoots regeneration, half strength Murashige and Skoog (MS), Celosia sp.

\section{INTRODUCTION}

Various factors should be considered in developing plant tissue culture technique. One of the most important factors governing the in vitro shoots regeneration is largely determined by the composition of the culture medium (Rashid et al., 2000). The basic Murashige and Skoog (MS) medium (Murashige and Skoog, 1962) is the most widely used media. However, the amounts of the various ingredients in the medium vary for cultures of different plant species. Much number of researchers influenced to find alternatives materials to substitute alternatives to gelling agents, use of household sucrose, and some medium components objectively to reduce cost in media culture preparation. For example Raghu et al.

\footnotetext{
*Corresponding author. E-mail: norhayati.daud@fsmt.upsi.edu.my. Tel: 605-4505074. Fax: 605-4583616.
}

(2007) have tried household sugar and tap water to substitution laboratory sucrose and double distilled water used in plant tissue culture. Besides successful in promoting the plantlet regeneration, by using the substitution items provide cost reducing in media culture preparation. This present study aims at developing a cost effective sources for in vitro micro-propagation of Celosia sp. The shoots production or cultures growth is influenced by the physical consistency of the culture medium. Gelling agents are added to the culture medium that acts as supportive agents to increase its viscosity. As a result, plant tissues and organ cultures remain above the surface of the medium.

Many gelling agents are used for plant tissue culture media, such as agar technical Oxoid, agarose, phytagel and gelrite (Debergh, 1983). Agar is the most commonly used as gelling agent for media preparation (Afrasiab and Jafar, 2011). From more than 100 years ago (Henderson and Kinnersely, 1988) until today, agar has been widely 
used as a gelling agent in plant tissue culture technique. This is because Henderson and Kinnersely (1988) reported its stability, high clarity and non toxic nature.

Several researchers reported various types of flour act as alternatives to agar. Prakash et al. (1993) have found options of alternatives gelling agent such as wheat flour, potato starch, rice powder, laundry starch, sago and semolina. Bhattacharya et al. (1994) and Naik and Sarkar (2001) used sago as cheaper gelling agent for potato regeneration. Second researcher studied on potato regeneration, Gerbe and Sathyanarayana (2001) used commercial cassava and sago as gelling agents. They found that the alternatives gelling agents were promoting potato regeneration. Other researchers tried to prepare the media by mix agar and other gelling agent at different quantity. From Mohamed et al. (2009) study, combination of agar with commercial corn and potato starch are efficient for potato regeneration using nodal explants. Maliro and Lamerck (2004) worked with cassava flour and found that the gel was improved by mixing with some agar. While, Zapata (2001) successfully reduced the cost of banana tissue culture by mixing corn and potato starch with gelrite as alternative gelling agent.

A large number of complex additives like coconut water, banana pulp, peptone, tomato juice, slap honey and beef extract, can be very effective in providing undefined mixture of organic nutrients and growth factors (Aktar et al., 2007). From the previous study, Rahman et al. (2004) demonstrated that the addition of potato, corn and papaya extract at various concentrations able to enhanced the growth of the calli of the Doritaenopsis orchid, and promoted the regeneration of protocorm-like bodies (PLBs) from the calli. While Prakash et al. (2002) explained plant extracts such as coconut milk, banana extract, and tomato juice can be very effective in providing undefined mixture of organic nutrients and growth factors.

This study was undertaken to observe the interaction effects of the modification of MS composition especially the quantity of MS powder and different gelling agents that are corn flour, rice flour, and cassava flour and potato starch on shoots regeneration of Celosia sp. in stem segment cultures. Attempts were made to evolve a low cost micro-propagation technology by adopting low cost substituent in the culture medium to make this system can be applied as an approach in basic educational of biotechnology.

\section{MATERIALS AND METHODS}

The study was carried out in the Laboratory B2.5, Institute of Biological Sciences, Faculty of Sciences, University of Malaya, Kuala Lumpur, Malaysia between June 2010 and March 2011.

\section{Preparation of stock plants}

In this experiment, explants used were seed of Celosia sp. Preparation of stock plant was done in a clean and sterile condition.
Firstly, the seeds of Celosia sp were washed three times using distilled water to remove impurities and microorganism on the seed surface. Next, the seeds were soaked with $100 \%$ Clorox solution (sodium hypochlorite) and added with two drops of Tween-20 for five minutes. Then, seeds were shaken in $70 \%$ Clorox solution, 50 , 30 and $20 \%$ for 2 to 3 min. Seeds of further rinsed with distilled water and $70 \%$ alcohol for one minute. The last washing stage used sterile distilled water for 4 to 5 times. Celosia sp sterile seeds were cultured in basic MS medium alone. After a period of 6 to 8 (2 months-old) of Celosia sp weeks for growth, explants were randomly selected for use as stock plantlets. In carrying out this study, the stem segments of Celosia sp were used as explants.

\section{Preparation of extract}

The coconut water samples were taken directly from the young coconut. Young coconuts are those that were harvested early. Their meat is soft and chewy, and they still have their brown hairy husks. Coconut water filtered to remove impurities from palm kernel, coconut bark or coconut husk.

\section{Preparation of culture media}

Throughout the study, different strength of MS (Murashige and Skoog, 1962) medium was used for the experiments. Half strength MS (2.2 g/l MS powder) basal medium and medium without MS (0 $\mathrm{g} / \mathrm{l})$ were used as the initiation medium. Preparation of media as the terms of basic medium by adding $30 \mathrm{~g} / \mathrm{l}$ of household sugar , 100 $\mathrm{g} / \mathrm{l}$ for gelling agent and $70 \mathrm{ml}$ young coconut water that had been prepared beforehand are added to the solution of basic medium. The $\mathrm{pH}$ of the medium was adjusted to 5.8 using $0.1 \mathrm{~N} \mathrm{NaOH}$ or 0.1 $\mathrm{N} \mathrm{HCl}$ solutions prior to the autoclaving of the medium.

\section{Culture conditions}

In each vial which was filled with culture media, $2 \mathrm{~cm}$ explants of stem segment were placed for the inoculation of Celosia sp. The culture within 8 weeks were controlled under room condition which are light intensity $\left(1000 \mu \mathrm{mol} / \mathrm{m}^{2} / \mathrm{s}\right)$, temperature at $25 \pm 1{ }^{\circ} \mathrm{C}$ and 70 to $80 \%$ relative humidity and $16 / 8 \mathrm{~h}$ light/darks of photoperiod.

\section{Experimental design}

The number of shoots per explants was recorded every week for 8 weeks in culture. Thirty replicates were made and the mean of replication were calculated. The data were subjected to analysis of variance (ANOVA) using SPSS version 16 statistical package. The values with $p<0.05$ were considered as significant. The differences mean number of shoot regeneration was contrasted using Tukey's test.

\section{RESULTS}

Throughout the study, different strengths of MS (Murashige and Skoog, 1962) medium and variety of alternatives gelling agent were reviewed. Combinations of half strengths MS basal medium or medium without MS substances interact with four different alternatives gelling agent which were corn flour, cassava flour, rice flour and potato starch. Stem segment explants were cultured in media containing a half and without strength 
Table 1. Mean number of in vitro shoots regeneration derived from stem segment explants after eight weeks cultured in media containing half strength MS and media without MS.

\begin{tabular}{lcc}
\hline \multirow{2}{*}{ Alternative gelling agent } & \multicolumn{2}{c}{ Number of shoots regeneration } \\
\cline { 2 - 3 } & $1 / 2 \mathbf{M S}$ & $\mathbf{0} \mathbf{M S}$ \\
\hline Corn flour & $10.40 \pm 5.86^{\mathrm{ab}}$ & $4.16 \pm 2.36^{\mathrm{ab}}$ \\
Cassava flour & $9.13 \pm 4.88^{\mathrm{a}}$ & $2.80 \pm 1.86^{\mathrm{a}}$ \\
Rice flour & $7.13 \pm 4.76^{\mathrm{a}}$ & $3.43 \pm 1.94^{\mathrm{a}}$ \\
Potato starch & $12.33 \pm 7.27^{\mathrm{ab}}$ & $3.90 \pm 2.61^{\mathrm{ab}}$ \\
\hline
\end{tabular}

Values are means \pm S.D. $(n=14)$ followed by the same letters are not significantly different at $5 \%$ level by Tukey's test.

concentration of MS in combination with $100 \mathrm{~g} / \mathrm{l}$ of alternative gelling agents and $70 \mathrm{ml} / \mathrm{l}$ coconut water. Table 1 shows the number of shoots responses to in vitro culture in using different quantity of MS supplement on different type of alternative gelling agents. Result reported the highest number of shoots produced using combination of potato starch and $1 / 2$ MS (12.33 \pm 7.27$)$ showed in Figure $1 \mathrm{~b}$ was far more than the medium does not contain MS $(3.90 \pm 2.61)$ as shown in Figure $2 \mathrm{~b}$.

$1 / 2$ MS interaction with young coconut water plus corn flour, rice flour, cassava flour and potato starch, respectively showed more effect on shoots regeneration of Celosia sp. stems cultures over others at all medium without the MS. The interaction showed no significant difference $(P>0.05)$ in the number of regenerated shoots.

\section{DISCUSSION}

$1 / 2$ MS medium in plant media culture showed more response to shoot regeneration. This might be due to nutrients composition, considered to be major sources of variation in plant tissue culture (Khanna and Raina, 1998) and higher nitrate, sulphate and relatively lower phosphate content of $1 / 2 \mathrm{MS}$. Composition and quantity of nutrients in MS medium have significant effects on rate of cell growth, differentiation and cell totipotency. 1/2 MS used in media culture represented the optimum quantity and this result was approved by Kuntal et al. (2006) and Kamla et al. (2009) but comparing with full strength of MS.

As reported by Deb and Pongener (2010), agar substance often used in plant tissue culture as supporting agent, but because of the relatively high material costs caused them to do research for alternative materials with lower cost. Instead of high price of pure grade agar, there are some doubts about its nontoxic nature that influenced researcher to find alternatives material (Sharifi et al., 2010). Pierik (1989) and Nagamori and Kobayashi (2001) stated cheaper agar alternatives include various types of starch and gums have been investigated in commercial micro propagation. Commercial starch or flour are used as a supporting agent containing a high amount of starch, vitamin $\mathrm{C}$ and carbon sources (carbohydrates), and a low amount of other minerals. However, the content of these materials depends on the type of flour and variety of plant that produce these. From the experiments carried out, it clearly indicates organic and supporting substitutes are easily available and there were a big different in cost as stated in media 1 and 2 compared to the control media in Table 2. With saving, the already low prices of alternatives gelling agent can be used as substitute in plant tissue culture method.

Many undefined supplements such as organic additives were employed in early tissue culture media and now it is a common practice to improve the growth of in vitro. In this present study, $70 \mathrm{ml}$ of young coconut water was supplemented in the media culture. The use of young coconut water acts as a plant growth regulator that gives a better response on plant tissue culture. According to George (1993), coconut water is composed of many amino acids, nitrogenous compounds, inorganic compounds, organic acids, carbon sources, vitamins and growth regulators such as cytokinin and auxin. Yong et al. (2009) reported in their study that coconut water contains mainly $94 \%$ of water and growth promoting substances, but as specified by George (1993), it can influence in vitro cultures. In a number of plant species, regeneration improvement was achieved by augmenting culture medium with coconut water (Maddock et al., 1983; Mathias and Simpson, 1986; Al-Khayri et al., 1992; Boase et al., 1993; Nasib et al., 2008). However, in view of associated costs, the use of young coconut in the preparation of $1 \mathrm{~L}$ culture media, there is no substantial savings when compared with the use of hormones in the control media. The price of young coconut water and hormones are the same as shown in media 1 and 2 compared with media 3 in Table 2.

The carbon sources such as grade sucrose that is often used in the micro-propagation of plants at laboratory contribute about $34 \%$ of the production cost (Demo et al., 2008). Sucrose has been reported as a source of both carbon and energy (Bridgen, 1994). Sugar was sucrose derived from sugar cane, in which the sucrose content in sugar is a combination of a glucose molecule with a molecule of fructose. Zapata (2001) cited in Kumara et al. (2010) reported success in reducing by $90 \%$ the cost of tissue culture banana trees are carried out due to the use 


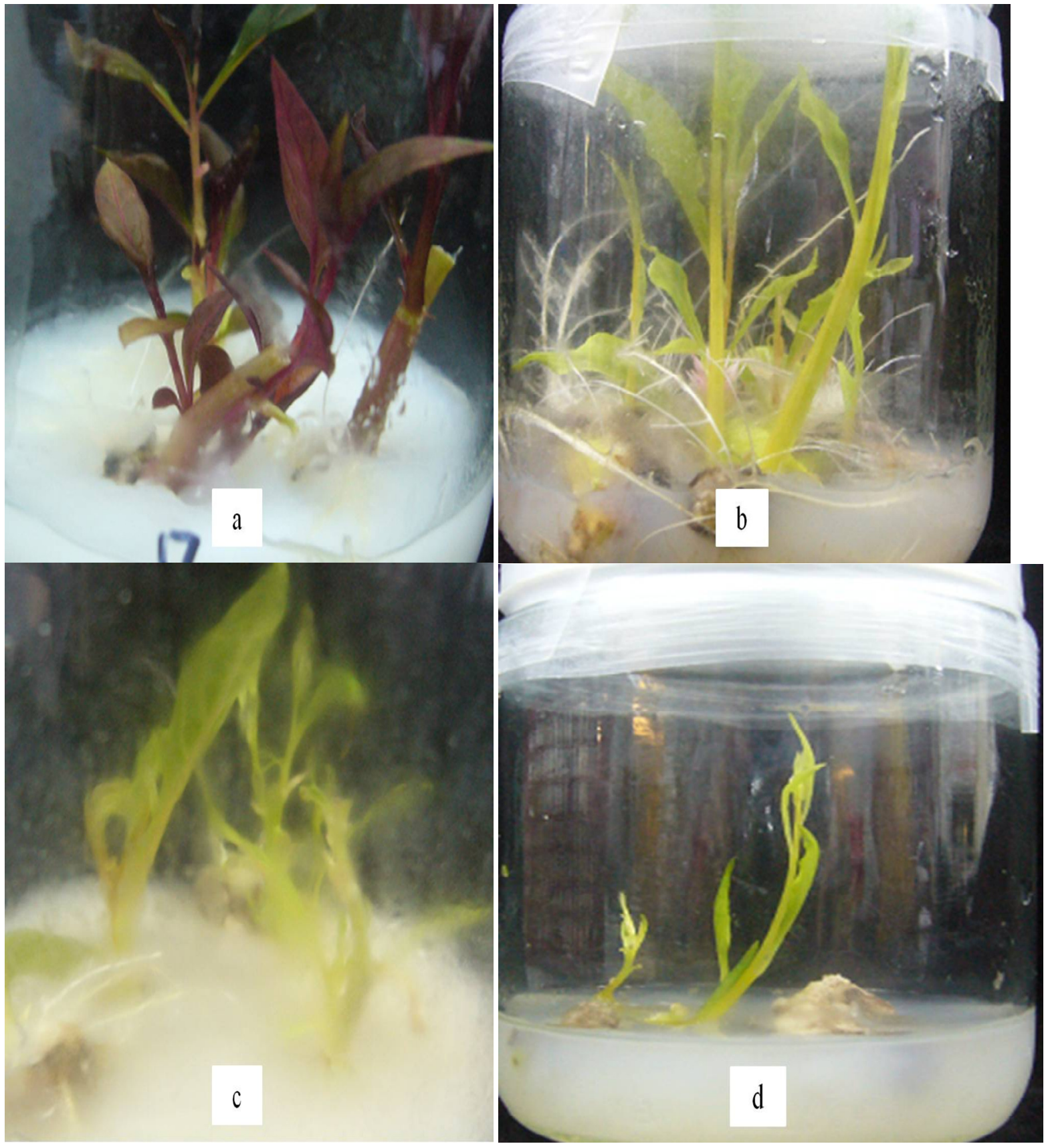

Figure 1. In vitro regenerated shoots from stem segments of Celosia $\mathrm{sp}$ cultured in media ( $1 / 2$ MS) with different combination of; (a) $100 \mathrm{~g} / \mathrm{I}$ corn flour $+70 \mathrm{ml} / \mathrm{l}$ young coconut water, (b) $100 \mathrm{~g} / \mathrm{I}$ potato starch $+70 \mathrm{ml} / \mathrm{l}$ of young coconut water, (c) $100 \mathrm{~g} / \mathrm{l}$ rice flour starch $+70 \mathrm{ml} / \mathrm{l}$ of young coconut water, and (d) $100 \mathrm{~g} / \mathrm{I}$ cassava flour $+70 \mathrm{ml} / \mathrm{I}$ of young coconut water.

of sucrose being replaced with table sugar. The quality and performance of plantlets grown on sucrose grade 1 and on local commercial sugar, specifically white and brown sugar resulted in all the sources of carbon fostered vigorous plantlet growth (Demo et al., 2008). Many research laboratories have used table sugar in the plant propagation medium (Kaur et al., 2005). Cost difference between household sugar and laboratory grade sucrose is quite big as shown in Table 2 and is about $97 \%$ difference. For the fact that laboratory grade sucrose is expensive, the use of $30 \mathrm{~g} / \mathrm{l}$ household sugar can be proposed replacing the $30 \mathrm{~g} / \mathrm{l}$ sucrose as a way to reduce medium costs. Further studies should be conducted to identify the use of sugarcane juice directly to replace sugar as the induction factor of shoot regeneration. Buah et al. (2011) reported that costs of providing culture 


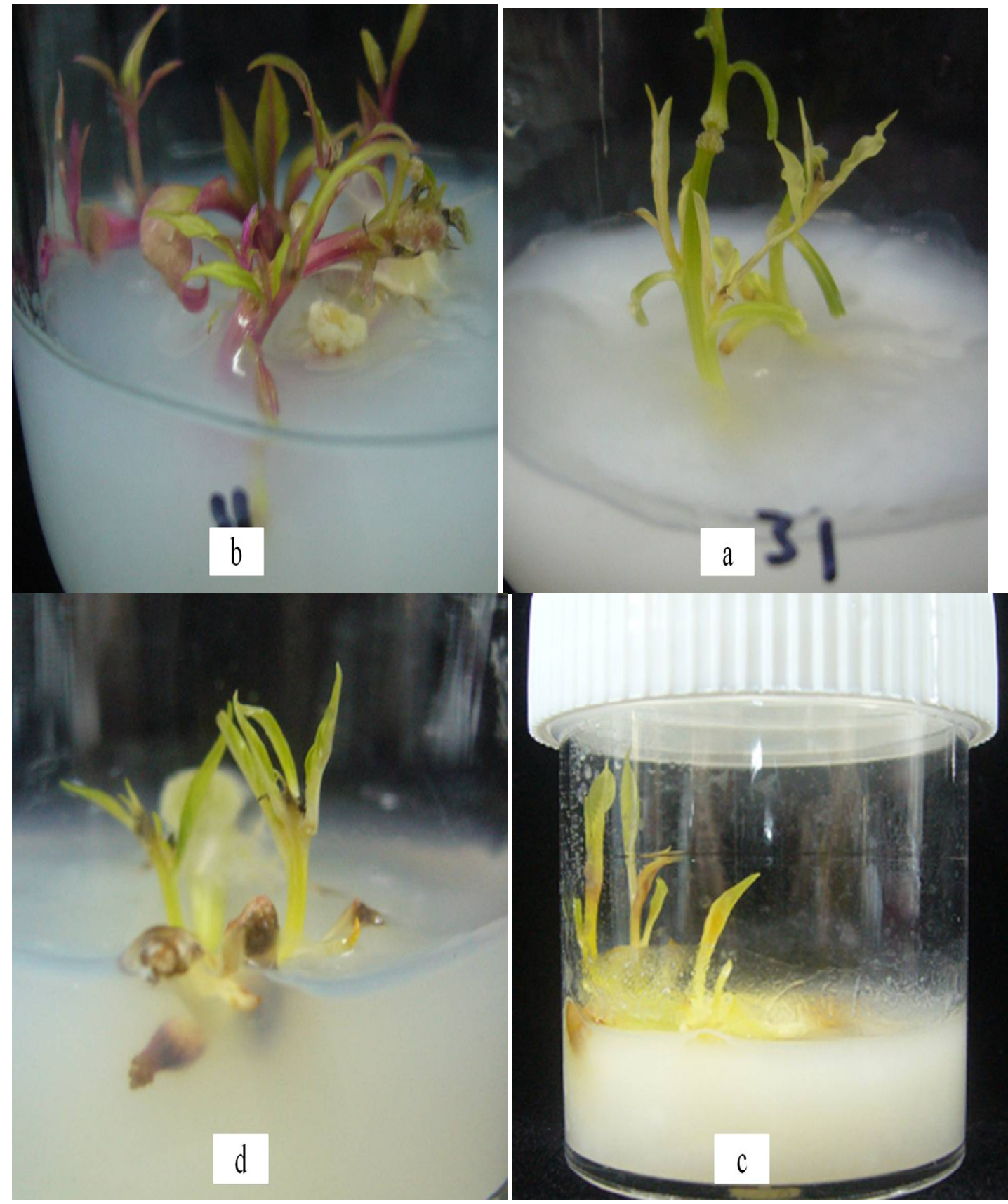

Figure 2. In vitro regenerated shoots from stem segments of Celosia sp cultured in basis media (without MS) with different combination of; (a) $100 \mathrm{~g} / \mathrm{l}$ corn flour $+70 \mathrm{ml} / \mathrm{l}$ coconut water, (b) $100 \mathrm{~g} / \mathrm{I}$ potato starch $+70 \mathrm{ml} /$ I of young coconut water, (c) $100 \mathrm{~g} / \mathrm{l}$ rice flour starch $+70 \mathrm{ml} / \mathrm{l}$ of young coconut water, and (d) 100 $\mathrm{g} /$ I cassava flour $+70 \mathrm{ml} / \mathrm{l}$ of young coconut water.

media using sugarcane juice are cheaper than using laboratory grade sucrose.

The replacement of medium components including quantities of MS powder can reduce costs to medium preparation. In a study conducted on Celosia sp, the physiological effects are not observed on the formation of shoots in media containing a replacement for the current period of explants culture. From the observation, all the shoots produced during the culture period are in good health. Referring to the medium cost and the number of shoots regeneration obtained from Celosia sp stem segments cultures, the cost options of media ingredients with half strength MS and combination with alternative gelling agents such as corn flour, rice flour, cassava flour and potato starch, and young coconut water used during this study can be utilized in cultures of any other species. 
Table 2. Comparison of medium costs to preparing one liter of medium.

\begin{tabular}{|c|c|c|c|}
\hline Medium & 1 & 2 & 3 (control) \\
\hline Combination & $\begin{array}{l}\text { Young coconut water }{ }^{* *}+1 / 2 \mathrm{MS} \text { powder }+ \\
\text { gelling agent (CF, RF, CvF and PS) }+ \\
\text { household sugar. }\end{array}$ & $\begin{array}{l}\text { Young coconut water + gelling agent(CF, RF, } \\
\text { CvF and PS) + household sugar (without MS } \\
\text { powder) }\end{array}$ & $\begin{array}{l}\text { MS powder }+2.0 \mathrm{mg} / \mathrm{L} \text { BAP }+1.0 \mathrm{mg} / \mathrm{L} \\
\mathrm{NAA}+\text { vitamins }+ \text { agar }+ \text { laboratory } \\
\text { grade sucrose }\end{array}$ \\
\hline Cost $(\mathrm{RM})^{*}$ & $\begin{array}{l}1.00+16.50+(C F=0.30 ; R F=0.40 \\
C v F=0.30 ; P S=1.50)+0.07\end{array}$ & $\begin{array}{l}1.00+(C F=0.30 ; R F=0.40 ; C v F=0.30 ; P S= \\
1.50)+0.07\end{array}$ & $33.00+0.24+0.003+0.28+4.48+2.70$ \\
\hline $\begin{array}{l}\text { Cost }(\mathrm{RM})^{*} \quad \text { with } \\
\text { different gelling agent }\end{array}$ & $\begin{array}{l}\text { i. } C F=R M 17.87 \\
\text { ii. } R F=R M 18.01 \\
\text { iii. } C v F=R M 17.87 \\
\text { iv. } P S=R M 19.07\end{array}$ & $\begin{array}{l}\text { i. } C F=R M 1.37 \\
\text { ii. } R F=R M 1.51 \\
\text { lii. } C v F=R M 1.37 \\
\text { iv. } P C=R M 2.57\end{array}$ & $\mathrm{RM} 40.70$ \\
\hline $\begin{array}{l}\text { Highest number of } \\
\text { shoots regenerated }\end{array}$ & $\begin{array}{l}\text { i. } C F=10.40 \pm 5.86 \\
\text { ii. } R F=7.13 \pm 4.76 \\
\text { iii. } C v F=9.13 \pm 4.88 \\
\text { iv. } P S=12.33 \pm 7.27\end{array}$ & $\begin{array}{l}\text { i. } C F=4.16 \pm 2.36 \\
\text { ii. } R F=3.43 \pm 1.94 \\
\text { iii. } C v F=2.80 \pm 1.86 \\
\text { iv. } P S=3.90 \pm 2.61\end{array}$ & $15.50 \pm 1.67$ \\
\hline
\end{tabular}

$\mathrm{CF}=$ Corn flour; $\mathrm{RF}=$ Rice flour; $\mathrm{CvF}=$ Cassava flour; $\mathrm{PS}=$ Potato starch. ${ }^{*} \mathrm{RM}-$ Ringgit Malaysia. ${ }^{* *}$ Means cost of coconut water $=\mathrm{RM} 1.00 .{ }^{* *} \mathrm{Cost}$ of household sugar $=\mathrm{RM} 2.30 / \mathrm{kg}$.

\section{REFERENCES}

Afrasiab H, Jafar R (2011). Effect of different media and solidifying agent on callogenesis and plant regeneration from different explants of rice (Oryza sativa L) varieties super basmati and IRRI-6. Pak. J. Biol. Sci. 43(1): 487-501.

Aktar S, Nasiruddin KM, Khaldun ABM (2007). Organogenesis of Dendrobium orchid using traditional media and organic extracts. J. Agric. Rural Dev. 5: 30-35.

Al-Khayri JM, Huang FH, Morelock TE, Buasharar TA (1992). Spinach tissue culture improve with coconut water. HortSciences. 27: 357-358.

Bhattacharya P, Dey S, Bhattacharya BC (1994). Use of low cost gelling agents and support matrices for industrial scale plant tissue culture. Plant Cell Tissue Organ Cult. 37: 15-23.

Bridgen MP (1994). A review of plant embryo culture. Hort. Sci. 29: 1243-1245.

Boase MR, Wright S, McLeay PL (1993). Coconut milk enhancement of axillary shoots growth in vitro of kiwifruit. $\mathrm{N}$. Z. J. Crop Hort. Sci. 21: 171-176.

Buah JN, Tachie-Menson JW, Addae G, Asare P (2011). Sugarcane Juice as an Alternative Carbon Source for in vitro Culture of Plantains and Bananas. Am. J. Food
Technol. 6: 685-694.

Deb CR, Pongener A (2010). Search of alternative substratum for agar in plant tissue culture. Current Sci. 98: 99-102.

Debergh PC (1983). Effects of agar brand and concentration on the tissue medium. Physiol. Plant. 59: 270-276.

Demo P, Kuria P, Nyenda AB, Kahangi EM (2008). Table sugar as an alternative low cost medium component for in vitro micro-propagation of potato (Solanum tuberosum L.). Afr. J. Biotechnol. 7: 2578-2854.

Gerbe E, Sathyanarayana BN (2001). Tapioca: A new and cheaper alternative to agar for direct in vitro shoo regeneration and micro tuber production from nodal cultures of potato. Afr. Crop Sci. J. 9: 1-8.

George EF (1993) Plant Propagation by Tissue Culture. 2nd Edn. Exegetics Ltd., England.

Henderson WE, Kinnersley AM (1988). Corn starch as an alternative gelling agent for plant tissue culture. Plant Cell Tissue Organ Cult. 15: 17-22.

Khanna HK, Raina SK (1998). Genotype culture media interaction effects on regeneration response of three indica rice cultivars. Plant Cell, Tissue Organ Cult. 52: 145-153.

Kamla I, Alromaihi KB, Khaled M, Sulaiman E (2009). Influce of different media on in vitro roots and leaves od Date Palm somtic Embryos Cvs. Kapkap and Tharlaj. AmericanEurasim J. Agric. Environ. Sci. 6:100-103.

Kaur R, Gautam H, Sharma DR (2005). A low cost strategy for micropropagation of strawberry (Fragari ananassa) cv. Chandler. Proceedings of the VII International Symposium on Temperate Zone Fruits in the Tropics and Subtropics, 2005, Acta Horticult, pp. 129-133.

Kumara SM, Sudapta KM, Balasubramanya S, Anuradha M (2010). Effect of different carbon sources on in Vitro morphogenetic responses of Patchouli (Pogostemon calbin Benth). J. Phytol. 2(8): 11-17.

Kuntal D, Raman D, Rajeasekharan PE (2006). Establishment and maintenance of callus of Stevia rebaudiana Bertoni under aseptic enviorment. Natural Prod. Radience, 5: 373376.

Maddock SE, Lancaster VA, Risiott R, Franklin J (1983). Plant regeneration from cultured immature embryos and inflorescences of 25 cultivar of wheat (Triticum aestivum). J. Exp. Bot. 34: 915 - 926.

Mathias RJ, Simpson ES (1986). The interaction of genotype and culture medium on the tissue culture responses of wheat (Triticum aestivum L.) callus. Plant Cell Tisssue Organ Cult. 7: 31-37. 
Mohamed MAH, Alsadon AA Mohaidib MS (2009). Corn and potato starch as an alternative for $<i>$ Solanum tuberosum $</ i>$ micropropagation. Afr. J. Biotechnol. 8: 9199 -9203.

Murashige T, Skoog $F$ (1962). A revised medium for rapid growth and bioassay with tobacco tissue cultures. Physiol. Plant. 15: 473-497.

Nagamori E, Kobayashi T (2001). Viscous additive improves micropropagation in liquid medium. J. Biosci. Bioengin. 91: 283-287.

Naik PS, Sarkar D (2001). Sago: an alternative cheap gelling agent for potato in vitro culture. Biol. Plant. 44: 293-296.

Nasib A, Ali K, Khan S (2008). An optimized and improved method for the in vitro propagation of kiwifruit (Actinidia deliciosa) using coconut water. Pak. J. Bot. 40: 2355-2360.

Pierik RLM (1989). In vitro culture of higher plants. Martinus Nijhoff, Dordrecht.

Prakash S (1993). Production of ginger and turmeric through tissue culture methods and investigations into making tissue culture propagation less expensive. PhD. Thesis, Banalore Univ. Bangalore

Prakash S, Hoque MI, Brinks T (2002). Culture media and containers in low cost options for tissue culture technology in developing countries. Proceeding of Technical Meeting, Aug. 26-30, FAO/IAEA Division of Nuclear Techniques in Food and Agriculture, Austria. Vienna, pp. 2940.

Raghu AV, Martin G, Priya V, Geetha SP, Balachandran I (2007). Low cost alternatives for the micropropagation of Centella asiatica. J. Plant Sci. 2: 592-599.
Rahman ARMM, Islam MO, Prodhan AKMA, Ichihashi S (2004). Effects of complex organic extracts on plantlet regeneration from PLBs and plantlet growth in the Doritaenopsis orchid. Jpn. Agric. Res. Q. 38: 55-59.

Rashid H, Toriyama K, Qureshi A, Hinata K, Malik AK, (2000). An improve method for shoot regeneration from calli of indica rice (Basmati). Pak. J. Biol. Sci. 3: 2229-2231.

Sharifi A, Moshtaghi N, Bagheri A (2010). Agar alternatives for micropropagation of African violet (Saintpaulia ionantha). Afr. J. Biotechnol. 9(54): 9199-9203.

Yong JWH, Ge L, Ng YF, Tan SN (2009). The chemical composition abd biology properties of coconut (Cocos mucifera L.) water. Molecules, 14: 5144-5164.

Zapata A (2001). Cost reduction in tissue culture of banana. Int. Atom Energy Labs. Agric. And Biotech. Lab Austria. 